\title{
The Role of Sheikh Dr. H. Abdul Karim Amrullah in Developing Muhammadiyah in Maninjau West Sumatera
}

\author{
Muslim $^{1}$, Ihsan ${ }^{2}$ \\ ${ }^{1,2}$ Faculty of Postgraduate Education History University of Eleven March Surakarta, Indonesia \\ 1mus161194@gmail.com, ${ }^{2}$ ihsan.1111@yahoo.com
}

\begin{abstract}
Keywords:

Role,

Sheikh Dr. Abdul Karim

Amrullah,

Muhammadiyah.

This study aims to describe the role of Sheikh Dr. Abdul Karim Amrullah in developing Muhammadiyah in Maninjau. This type of research is qualitative research with historical methods, and heuristic measures, source criticism, interpretation, and historiography. The theory and approach in this research is the phenomenological approach and the theory of study figures. The results obtained from this study first, Sheikh Dr. H. Abdul Karim was a scholar who was born in 1879 Ad and died in 1945 A.D. He was born to a religious family, since childhood he has received a religious education from both parents and then continued his education through non-formal course. Secondly, the role of Sheikh Dr. H. Abdul Karim Amrullah in developing Muhammadiyah in Maninjau, backed by the religious condition of Maninjau that time has been mixed only, is no longer distinguished where the teachings of pure Islam and which are mixed with bid'ah, and Khurafat. This is what prompted Sheikh Dr. H. Abdul Karim Amrullah to make updates to Islam that has been corrupted in Maninjau. Therefore, to accelerate this renewal. He was the pioneering establishment of Muhammadiyah in Maninjau, after his return from Java in 1925 A.D.
\end{abstract}

Article History:

Received: $12-10-2018$

Revised : 23-12-2018

Accepted: 28-12-2018

Online : $30-12-2018$

\author{
This is an open access article under the CC-BY-SA license \\ Crossret \\ https://doi.org/10.31764/ijeca.v1i3.2120
}

\section{A. INTRODUCTION}

Historically, before the inclusion of various religions to Minangkabau, the people in addition to obey customary regulations, also have embraced pre-religious beliefs, both in the form of animism and dynamism. The realization and form of this belief, they believe in the delicate beings that are considered to be harmful to man, so that he should be given offerings and accompanied by the readings of certain spells. Even today, in some communities, there is still such a belief especially in rural communities (Kamal, 2005). Similar to the various ethnic groups inhabiting the archipelago, Minangkabau Malay people embrace the original belief of animism and dynamism as well. Life in this animism and dynamism lasts so long, that they receive religious influences from the outside. The first religion to enter the archipelago is Hindu and Buddhism. The 6th or 7th century A.D., both of them are already on the island of Sumatra (Kamal, 2005). Brahmana Hindu Religion is estimated to enter Minangkabau in the 5th century AD, followed by the Hinayana Buddhist religion in the 7th century AD and Mahayana Buddhism in the 7 th century AD until the 10th century AD. The inclusion of these religions, both directly 


\section{I IJECA (International Journal of Education and Curriculum Application)}

Vol. 1, No. 3, December 2018, pp. 5-14

brought by the migrants from the Land of Hindustan (India) and those who came from the Kingdom of Majapahit (Kamal, 2005).

The inclusion of Hinduism and Buddhism to Minangkabau, is not able to peer the customary position as a guideline and rules adopted by the community. The position of the two religions is not as strong as customary and not as powerful as Hindu and Buddhist influences in Java when Islam comes. The influence is not profound and also does not leave old scars. Both religions are not able to make up, so that there has not been many places of teaching and broadcasting of the religion in this area (Kamal, 2005). Regarding the weakness of Hindu and Buddhist influences in Minangkabau people's lives, Hamka stated that despite being Hindu and Buddhist, the Minangkabau people have already composed their own culture and Customs, so that the coming of Hinduism and Buddhism has no effect (Hamka, 1982). The customary structure and its governance are based on two adjustments, namely Koto Piliang and Bodi Chaniago. Each nagari is composed of the community on the basis of the word consensus and the emperor is merely symbolic, because the people of Indonesia are governed by its chief tribe (Hamka, 1982).

Although the influence of Hinduism and Buddhism is not so strong in the Minangkabau society before the entry of Islam, because of the indigenous people who dominate the behavior of society, but the remainder and traces of animism-dynamism still present in the lives of its people before the renewal in Minangkabau. As Hamka explained that throughout the Minangkabau in those days religious journeys have been very backward. It is indistinguishable where the religion is pure and which is shirk, bid'ah and where religion is mixed only. The amulets of the arm are suspended at the waist of people, sometimes religious teachers become selling amulets. Various graves of scholars who were regarded as sacred as a place of vow and intent (Hamka, 1982). The arrival of Islamic religion to Minangkabau can enhance the Minangkabau tradition, because there is a point of similarity from the fundamentals of indigenous teachings with the teachings of Islam. At least has the same intent and idea of achieving the goal of community life. The movement of the priests who emerged (1803-1837 A.D.), caused the position of the religions to be ejected forward, outperform the indigenous peoples, so that the scholars received the designation "Tuanku" such as Tuanku Nan Renceh, Tuanku Imam Bonjol, and so forth. Whereas previously, the designation did not exist in the customary leaders, even the religious law at the time of the movement, almost in the position of customary law (Nain, 1988).

The radicalism of the Paderi group known as "Harimau Nan Salapan" (the Eight Tigers) raises concerns among the indigenous peoples, that the religion of Islam will eliminate the Minangkabau tradition so that the scholars will obliterate the indigenous peoples. This concern was increasingly torn up by the Dutch colonists, so the indigenous peoples rose against the Paderi with the help of the Dutch. Although it has since been between religious institutions and indigenous institutions conflict even continued in the form of a war, but this integration or mixing actually has begun since the presence of this religion in Minangkabau. The religion of Islam does not eliminate customs, but rather perfecting and Enslaves (Hamka, 1982). In Islamic fiqh law, "Urf" and "adat" in every country, which is good does not violate Islamic rules, is recognized as a reality. Islam is a strong addition to this rule alone. Therefore, the customary structure of the Koto Piliang and the Chaniago body is left to remain. The greatness of Minangkabau people, namely the name of Perpatih Nan Sabatang and Ketumanggungan remained preserved. Before the Islamic religion entered Minangkabau in the customary tradition has been made by Datuk Perpatih Nan Sabatang and Datuk Ketumanggungan about "death". If a member of the community dies, they need to be buried immediately at the 
designated place for each group (Kamal, 2005). In the customary rule is declared live the Batampek die Bakubuah, the grave lived in the Gadang house, the grave dies in the Tangah of the field, Sakik Basilau died Bajanguak. But the Minangkabau tradition does not recognize the rules of the cadaver according to Islam, such as the corpse must be in the bath, recite, be worshipped and so forth. Only after the Islamic religion was embraced, this rule was refined by the Islamic religion according to the teachings of Islam itself (Penghulu, 1978).

Although the harmony of the relationship between indigenous and religious Islam in Minangkabau is well-established, including during the post-Paderi society, but also denied the existence of certain customary applications that are not in accordance with the spirit or spirit of Islam. Especially this is related to the customs that have been traditions in certain Nagari-nagari, such as the tradition of combining chickens, drinking wine, gambling and so on. Speaking of the beginning of the Islamic Renewal movement in Minangkabau is not detached from discussing this movement in Indonesia in general. Because the Minangkabau area is the first region to perform the renewal movement in the homeland. It is said by Noer, that the Minangkabau region has an important role in spreading the ideals of renewal can be observed, at the time other regions still feel satisfied with their traditional practices (Noer, 1982). In fact, when seen early movements of the Islamic revival in Minangkabau (1784-1803 A.D.) which was established by Tuanku Nan Tuo leader Surau Syattariah in Koto Tuo Agam, is a purely social and religious movement. Tuanku Nan Tuo succeeded in collecting thousands of students coming from the other village of Syattariyah Surau in the midst of the people's economy, marked by the growth of agricultural economic centers of Acacia and coffee. The pure social and religious movement of Tuanku was trying to convince people of the importance of the five pillars of Islam and trying to live as a good Muslim. On another occasion try to persuade people in villages to accept how to trade according to Islamic law. This is a reflection of the Islamic Religious Renewal movement in Minangkabau which is more reform of Islamic religion in Minangkabau and purely religious intellectuals. However, according to Azra, Tuanku Nan Tuo's renewal movement was ongoing with the dramatic movement of the priest, given that not a few of Tuanku Nan Tuo's disciples were the main leaders of the Paderi movement, such as Tuanku Nan Renceh and Tuanku Imam Bonjol. However, if Tuanku Nan Tuo was more using persuasive method in his renewal, but the Paderi movement as we know it, did not hesitate to use violent means (Azra, 1989).

Although the Paderi movement can eventually disabled the Dutch, but has succeeded in deepening the penetration of Islam in the social interwoven Minangkabau in particular, and does not lack the long-term implications throughout Sumatra and Peninsular Malay. Among those implications according to Hamka was the growing moral consciousness and desire for their grandchildren to send his children to learn the deeper Islamic religion to the land of Mecca. Although the Dutch government has established the "King's School" in Bukittinggi, but who entered there only the sons of Kings. The children of the religion to the people were sent to learn by his parents (Hamka, 1982). Starting from the talks of the two assumptions above, relating to the method and approach of the clerics respectively in the Islamic Renewal movement in Minangkabau early 20th century entered a new chapter, post-movement of the Paderi. The new round is meant, because the renewal consists of the newly learned learned people from Mecca, upon arrival in the homeland, according to the term Azra, they are ready to become transmitters (shifting, broadcasters) major Islamic religious intellectual traditions from Islamic scientific centers in the Middle East to Nusantara (Indonesia) (Azra, 1989).

Scholars in human life are very important roles both as forming of the morality and moral of mankind as well as influence, guidance and Pengayom to the right path. The scholars do his role 
in their own consciousness and willingness, because without the urge to make changes from the ordinary to the more advanced, it will be impossible. One of the loyal disciples of Sheikh Ahmad Khatib Al-Minangkabawy as the reformer who returned to the homeland and became the focus of the discussion in this study is Sheikh DR. H. Abdul Karim Amrullah better known as "Haji Rasul". One of the scholars who developed the Muhammadiyah organization in order to purify the teachings of Islam on his care in Maninjau area in 1925-1941 ad, this proved by the recognition of the community and the government of Nagari Maninjau (Batang River) itself. Sheikh DR. H. Abdul Karim Amrullah is also known as a pioneer of young people's movements, which always concentrates on changing various changes for improvement, especially in the field of religious thinking. At the very least, there are two assumptions that can be attributed to the motive behind the renewal movement of Islamic education in Minangkabau. First, it was born by a sense of deep disappointment from scholars and scholar, to acquire social status in their society, which is certainly more political. Secondly, it is more purely a pure social and religious intellectual movement, because they are morally called to improve their society in religious life, economy and other social retardation.

With the widespread communication lines with the outside world, especially with the Middle Eastern scholars through its network, it is assumed that the role of Abdul Karim Amrullah's approach will be more frontal and explosiveness than the previous Paderi movement. In fact, the approach to the role of Abdul Karim Amrullah is a purely religious intellectual movement, in order to purify the teachings of Islam on its occupants. But in turn Abdul Karim Amrullah's role became politically, after the reformer figures were suspected by the Dutch. This political term, however, was not endeared by Abdul Karim Amrullah (Shaykh Abdul Karim Amrullah) who frankly said that he had no idea of political problems, he knew only religious issues and delivered them as they were, and there was no political potential. As has been explained above, in the year 1917 M Sheikh Dr. Abdul Karim Amrullah went to the land of Java and saw the Muhammadiyah movement up close. He sympathizes with the organization, but does not want to obey it. His belief in religion is not acceptable to him or the Minangkabau people from the Land of Java (Hamka, 1982). Judging from the development of this Organization since the establishment of $1912 \mathrm{AD}$, until the year $1917 \mathrm{M}$ activities are still limited (not developed) outside the area of Kauman, Yogyakarta. Only from 1920 M expanded in Java and in the following year 1921 A.D., it began to spread throughout Indonesia. This is where Sheikh DR. H. Abdul Karim Amrullah did a role in developing the organization of Muhammadiyah to Minangkabau generally and Maninjau in particular, after the return from his second visit from the island of Java.

According to Hamka, it is obvious that the first pioneer to bring Muhammadiyah organization to Maninjau is Sheikh DR. H. Abdul Karim Amrullah: Welcomed at Batang River (Maninjau) by his younger brother, H. Yusuf Amrullah, the scholar, who at that time was not yet Muhammadiyah his name but the safe joints of the pole Selamat and the new in 1925 A.D. He was named after Muhammadiyah (Hamka, 1982). Sheikh Abdul Karim Amrullah introduced Muhammadiyah to Maninjau, in June 1925 A.D., after returning from Java. He was very interested in the organization's activities in Java. The organization was established in 1912 ad by Abdul Dahlan, the reformed scholar of Java (Noer, 1982). After the founding of the Muhammadiyah branch in Maninjau as described above, he continued to propagat each of his opportunities. After Muhammadiyah stood in Maninjau, he also introduced the Muhammadiyah in Sumatera Thawalib, according to the explanation above, that on 20 June $1925 \mathrm{M}$ students of Sumatera Thawalib from Sungai Batang (Maninjau) in Padang Panjang established a group of 
Muhammadiyah studies in his advice, as Tabliqh Muhammadiyah aims to teach and train the disciples preaching (Edwar, 1981).

In addition he also established an office to store the many books, where he received his disciples came to study, and there the people studied and asked the laws. Among his disciples Abdul Hamid Tuanku Mudo, Rahmah El Yunisiyah, Adam Balai, and A. R. St. Mansur have developed their own its wings as well (Hamka, 1982). At Muara Pauh (Batang River), he would recommend establishing a Surau lesson committee for people who come to study once a week. Wednesday evening Tuesday evening studies at Muara Pauh Evening Wednesday Thursday evening the Koran in Kubu Mosque. Wednesday morning to recite all scholars at the Pole Khanah (library) Muara Pauh (Batang River), which is mainly in review is the Tafsir Al-Qur'an. Thus interested and enthusiastic he in developing Muhammadiyah in Maninjau at that time, so it can be said he was the first pioneer of the establishment of Muhammadiyah in Nagari Sungai Batang (Maninjau) is questionable, what exactly motivates him to develop this organization. In response, it was not separated from his struggle in developing the Muhammadiyah organization in Maninjau. He sees Muhammadiyah as a vehicle that can be stacked to further accelerate its renewal movement. Although Sheikh Abdul Karim Amrullah people who first took the organization of Muhammadiyah to Maninjau West Sumatera. Not only did he take Muhammadiyah to Maninjau (Batang River) west Sumatera, even on his way around Sumatra, always the Muhammadiyah that was propagated. Although he served as an inspirator and initiator of Islamic movement through Muhammadiyah, not only in Maninjau also in Minangkabau even in the homeland (Indonesia) in general (Marjohan, 2010).

But Sheikh Abdul Karim Amrullah, until the death is still not registered and does not register as a member of Muhammadiyah if only traced Sebab-musababnya, presumably is a few possibilities, first as an influential figure and well respected or the Jealousians Abdul Karim Amrullah would be able to position himself as Tongak Tuo, above all groups that are still relatively strengthened in Minangkabau. Second, as a pure Muhammadiyah lover Abdul Karim Amrullah presumably to perform in substantionalistic realm rather than playing behind a formalistic symbol (Marjohan, 2010). So the Muhammadiyah in West Sumatera generally and in particular in Maninjau can be said, raised in the Surau Sheikh Abdul Karim Amrullah at Batang River (Maninjau) (Kayo, 2007). Until now, there is no one area in Maninjau, which is not entered by the Muhammadiyah organization. Since that time emerged Mubaliqh-Mubaliqh Muhammadiyah in Minangkabau, which will broadcast the understanding of Muhammadiyah throughout the region in Indonesia, and will play an important role together the leader of Yogyakarta in shaping its mind and movement. The Muhammadiyah itself who was during the Congress in Bukittinggi in $1930 \mathrm{M}$ the number of members was about 24,000 members, which then in $1935 \mathrm{AD}$, became 43,000 members. Muhammadiyah reached the peak of progress in 1938 AD, with membership number 250. 000 members (A. B. Lapian, 2012). The organization also expanded its branches in various regions in the archipelago and finally had 834 mosques and places of worship, 31 public libraries, and 1. 774 School with the number of male Mubaliqh 5. 516 and Mubaliqh Women 2. 114. It can be said that the history of Islamic modernism in Indonesia is actually more related to the history of Muhammadiyah development (A. B. Lapian, 2012). This is a religious social phenomenon which is a question for researchers how was the background of Sheikh Dr. Abdul Karim Amrullah's role in developing Muhammadiyah in Maninjau (1925-1941). 


\section{B. METHODS}

The type of research used to assess the role of Sheikh Dr. H. Abdul Karim Amrullah in developing Muhammadiyah in Maninjau (1925-1941), it uses a qualitative research type, with the methods of historical research (Alian, 2012), with the steps: Heuristik, source criticism, interpretation, and historiography. Historical research method is a periodesation or stages taken for a study so that with existing abilities can reach the nature of history. A very important step in making historical analysis is to provide an approach and theory as a reference framework, to be used as a tool to analyze a study. So that in terms of study to be done, descriptions and reconstruction obtained will be determined by the type of approach used. In this case researchers use two approaches at once, which is a qualitative approach and a phenomenological approach. Qualitative approach is used to explain the phenomenon deeply through the collection of data in depth, qualitative research emphasizes the depth of data obtained by researchers, the deeper and details of the data obtained by researchers, the better the quality of this qualitative research., while the phenomenological approach is used to understand and describe a specific phenomenon that is profound and acquired the essence of the life experience of participants in a phenomenon. In this research researchers use the theory of character study. The study of the figure is an attempt to find, develop, collect data and information on the role of Sheikh Dr. H. Abdul Karim Amrullah in developing Muhammadiyah in Maninjau (1925-1941), systematically to improve or generate information and knowledge.

\section{RESULT AND DISCUSSION}

\section{The role of Sheikh Dr. H. Abdul Karim Amrullah in Developing Muhammadiyah in Maninjau}

The birth of Muhammadiyah at Sungai Batang Maninjau River is not separated from the great services of Sheikh Dr. H. Abdul Karim Amrullah. The departure of Haji Abdul Karim Amrullah to Java in 1925 A.D., to visit his daughter Fatimah the wife of A. R. Sutan Mansur, who turned out to be active in Muhammadiyah and was assigned the task to be the chairman of Muhammadiyah Branch Perkalongan (Djamal, 2014). Sutan Mansur was one of the leaders who included the first ranks in Muhammadiyah. Very vigorous Sutan Mansur attempted to advance and broadcast the Muhammadiyah Union in 1923 AD, and in 1924 M. Sutan Mansur has successfully unify the batik traders coming from Batang Maninjau River, and established the association with the name Nurul Islam (Hamka, 1982). In the village of Poncol, many men and women studied religion to Sutan Mansur. Sheikh Dr. H. Abdul Karim Amrullah, look closely, how people advance the Islamic religion by using the organization. Coinciding with the fasting month, the saw Tarawih prayer was completed, and at the end of the fasting month PKU (assistant General Affliction), one part of Muhammadiyah, dispensed zakat fitrah to poor poverty.

Batik merchants who have been looking at the light of religious affairs are now obedient (Hamka, 1982). From his Perkalongan (Haji Abdul Karim Amrullah) continued to Solo, from Solo directly to Yogyakarta to see other Muhammadiyah activities. There Haji Abdul Karim Amrullah met with the leaders of Muhammadiyah, especially with $\mathrm{H}$. Fakhruddin (Hamka, 1982). He saw the former charity and business of Muhammadiyah: schools, hospitals, poor hospital maintenance, orphans home care. The women who when Haji Abdul Karim Amrullah went to Java the first time in 1917 A.D., still open his head, in Kauman has been legally closed religiously. Be reflected in his eye space (Haji Abdul Karim Amrullah), the fate of Nagari Sungai Batang Maninjau River in particular and Minangkabau generally, has been damaged to perish, now must be renewed. Then, Haji Abdul Karim Amrullah went to Sungai Batang Maninjau River, together with Haji Abdul 
Karim Amrullah Come home also his brother Ja'far Amrullah who trade in Perkalongan (Hamka, 1982).

As if Haji Abdul Karim Amrullah returned from his travels, he was in the river Sungai Batang Maninjau listening to the news of his travels, which he saw, and which he heard. He told the inhabitants of Sungai Batang River. Haji Abdul Karim Amrullah met Sheikh Ahmad Soorkati in Perkalongan, in his praise to the Sudanese scholars because of his knowledge. He (Haji Abdul Karim Amrullah) meets also with the teachers of the Ahmadiyya Lahore, Mirza Wali Ahmad Baig. It was his with Mirza Ahmad Baig before H. Fakhruddin, so that since then, only the Muhammadiyah of Yogyakarta knew that Ahmadiyah was not as important as US (Muhammadiyah). It is explained to the community of Maninjau about Muhammadiyah with excited was. Apparently interested in the people of Batang Maninjau River with a description of him (Haji Abdul Karim Amrullah). Be at the pillar of safe joints safely, change the name of the safe joint of the pole with the name Muhammadiyah, at the end of 1925 M (Hamka, 1982).

The Assembly (Sendi Aman Tiang Selamat), stood before the hajj apostle went to Java at his recommendation (Haji Abdul Karim Amrullah).

Well, exchange the Muhammadiyah, so that there is our relationship with the large requirements (Muhammadiyah Yogyakarta) He said (Hajj Rasul) immediately asked the opinion of the Hajj Apostle (Kayo, 2007).

It is the first to say Muhammadiyah, in Batang Maninjau River standing and living. All Ninik Mamak, Alim Ulama, both male and female are all in the organization of Muhammadiyah, become Muhammadiyahlah nagari Batang River, Tanjung Sani, which has a population of not less than 12,000 inhabitants (Kayo, 2007). So at that time according to Hamka in my father's book said:

At that time, we still had a lesson with him (Hajj Rasul), learned to make speeches and also learn to compose. The speeches we speak in the course and debating club who always got the lead from him (Hajj Rasul), we collect. Then we took out a small magazine called Khatibul Ummah, I became the head of the center, meaning the speech that I composed it, I compiled into a plan, entered in Khatibul Ummah and underneath it is written, that time I (Hamka) began to compose in 1925 AD (Kayo, 2007).

As for his own (Haji Abdul Karim Amrullah), he did not enter the chairman or member of Muhammadiyah. He said (Haji Abdul Karim Amrullah), has been bound by the Persarikatan of Islamic religious teachers (PGAI), that the other Union will not be entered. After the first Muhammadiyah stood at Sungai Batang Tanjung Sani Maninjau, May 29, 1925 M. The establishment of Muhammadiyah in Padang Panjang 2 June 1926 M pioneered by Saalah Sutan Mangkuto (disciple of Haji Abdul Karim Amrullah), establishment of Muhammadiyah in the flat land Simabur 27 July 1927 M, pioneered by Datuk youngest, Murkan Sutan Marajo, H. Muchtar, Datuk Simarajo and others, followed by the Muhammadiyah of Bukittinggi 20 July 1928 AD, which was pioneered by M. Karim, H.M. Siddiq, H. Abu Samah, Datuk Mangulak Basa, Datuk Rajo Dilangik, TM. Mantari Danlain (Kayo, 2007). Overtaken again with the Muhammadiyah Kurai Taji 25 October 1929, which was pioneered by Buya Udin and others, subsequently following the Muhammadiyah Kubang District 50 City 25 December 1929 AD, which was pioneered by H.M. Khalil. Last Muhammadiyah Padang pioneered A. Gratitude and others (Kayo, 2007).

\section{Sheikh dr. H. Abdul karim amrullah's activity in developing muhammadiyah}

a. Broadcast Muhammadiyah

As researchers have explained above, that in the year 1925 M Haji Abdul Karim Amrullah has gone to the land of Java and saw the move of Muhammadiyah up close. He sympathizes with the organization, but does not want to follow. The great belief of Haji Abdul Karim Amrullah, in terms of religion, cannot be him or the man of Maninjau exempthe of Javanese soil (Hamka, 1982). Judging from the development of this Organization since the establishment of $1912 \mathrm{AD}$, until the year $1917 \mathrm{M}$ activities are still limited (not developed) outside the area of Kauman, Yogyakarta. Only from $1920 \mathrm{M}$ 
expanded in Java and in the following year 1921 A.D., it began to spread throughout Indonesia. This is where Sheikh Dr. H. Abdul Karim Amrullah did his role in developing the organization of Muhammadiyah to Minangkabau generally and Maninjau in particular, after the return from his second visit from the island of Java. In 1925 A.D. according to Hamka, it is obvious that the first pioneer who took the idea of bringing Muhammadiyah organization to Maninjau is Sheikh DR. H. Abdul Karim Amrullah is welcomed at Sungai Batang River (Maninjau) by his younger brother, H. Yusuf Amrullah, the scholars, which at that time has not been his name but the safe joints of the Pillar of heaven (kh1991 atib And only in 1925 A.D. He was in the name of the Muhammadiyah (Kayo, 2007).

b. Dr. Abdul Karim Amrullah criticizes Muhammadiyah

Haji Abdul Karim Amrullahnever had a big temper in Muhammadiyah in 1928 A.D., he saw that led or that gave the explanation of religion in Muhammadiyah generally in Minangkabau, especially in Sungai Batang Maninjau River only people who are good at talking, but not knowledge able. Many experts speech and a bit of his knowledge. Many of his deeds were seen by his belief, not based on religion. So many of the leaders, both men in Muhammadiyah and women in Aisyiah, only taqlid to the deeds in Yogyakarta. Other than that, there are also some deeds that according to the belief of Haji Abdul Karim Amrullah, do not come from religion. For example, collecting Zakat Fitrah to share with poor. Said Haji Abdul Karim Amrullah, Muhammadiyah is not entitled to collect it, which has zakat himself know more to whom they gave it. Women in speech before men, according to the belief of Hajj Abdul Karim Amrullah is unlawful, because it can bring libel, and the whole body of the woman is an aura. Likewise, although he agreed to pray in the field, he could not approve the woman's Prayer in the field (Hamka, 1982).

In some religious meetings, Haji Abdul Karim Amrullah has explained his founding (Haji Abdul Karim Amrullah) about it, but apparently there is no change. Then he did a book titled Mirror Continue, useful for the caretaker, the straight road seeker. In the book it is wide length Haji Abdul Karim Amrullah explained his opinion about the position of women in religion to the case, the boundaries of his loam, the size of his clothes and others. In 1930 A.D., Muhammadiyah Congress was in Bukittinggi. The Committee of Congress has decided that Siti Rasyidah a beautiful young woman of Aisyiah will speak before the rally, which is attended by men and women. Haji Abdul Karim Amrullah deliberately in law in the Congress, and the general manager of Muhammadiyah converted how great the role of Haji Abdul Karim Amrullah and his many help to the Muhammadiyah so that he felt reluctant to hajj Abdul Karim Amrullah. How else while his book was out stating the Haram female speech was struck by men. There is no other way, this must be resolved, being the rally two days away. It's near! The members of Muhammadiyah's general management are complete in Bukittinggi. And the general of Mas Mansur, then the assembly of the Tarjih of Muhammadiyah (Hamka, 1982).

No other way must be overcome. A meeting with Haji Abdul Karim Amrullah must be held, then the night before the Congress was opened. There was a meeting, from the party of Muhammadiyah, a great manager, Abdul Mu'thi, who was present. From the Hajj Abdul Karim Amrullah is present, Haji Abdul Karim Amrullah himself, Sheikh M. Djamil Jambek, Sheikh Abdul Wahab Amrullah the brother of Haji Abdul Karim Amrullah himself, who became the key to the completion is the attitude of his son, Mas Mansur showed no opposing attitude but demanded, so in the end, there is a deal that is not good women speech in the presence of men. Then the agreement arose that there was no saheeh Nash to rebue him, then that the prohibition did not reach the degree of haram. Only up to the degree of makruh. That is the right law. According to Hamka, this is once Haji Abdul Karim Amrullah is subject to the audience (Hamka, 1982).

c. The message of Dr. H. Abdul Karim Amrullah to Muhammadiyah

At the beginning of January 1941 A.D. the 29 th Muhammadiyah Congress will be held in Yogyakarta. Hamka explained in my father's book about the message of Hajj Abdul Karim Amrullah to Muhammadiyah: I (Hamka), as the consul of Muhammadiyah East 
Sumatera first stayed in West Sumatera. Visited A. R. Sutan Mansur Consul of West Sumatera. Before leaving Hamka went to see Haji Abdul Karim Amrullah his father. He said that since the return from Medan, Haji Abdul Karim Amrullah was called by Dutch government officials. Since the control to the Residen Haji Abdul Karim Amrullah given a variety of advice. So because of that, said Hajji Abdul Karim Amrullah:

The weight of the father thought that father would be discarded. Discarded or not is a matter of God. Dad has done his father's duty as a business. Only one will I tell the Great Muhammadiyah Manager! Continue to uphold Islam! Hold fast with the Qur'an and Sunnah! So long as it would be his father. But if the Muhammadiyah wasted it, and only expressed the mind of mankind, the father would fight against Muhammadiyah to divorce this wreck of my life! Give me this message to the very own of Mas Mansur! (Hamka, 1982).

\section{CONCLUSION AND SUGGESTIONS}

The results obtained from this study first, Sheikh Dr. H. Abdul Karim was a scholar who was born in 1879 Ad and died in 1945 A.D. He was born to a religious family, since childhood he has received a religious education from both parents and then continued his education through nonformal course. Secondly, the role of Sheikh Dr. H. Abdul Karim Amrullah in developing Muhammadiyah in Maninjau, backed by the religious condition of Maninjau that time has been mixed only, is no longer distinguished where the teachings of pure Islam and which are mixed with bid'ah, and Khurafat. This is what prompted Sheikh Dr. H. Abdul Karim Amrullah to make updates to Islam that has been corrupted in Maninjau. Therefore, to accelerate this renewal. He was the pioneering establishment of Muhammadiyah in Maninjau, after his return from Java in 1925 A.D.

Advised to the scholars, cleverly clever, and the community leaders who are souls and aspire to reform, to keep trying to carry out the task of renewal in order to cleanse the people in the understanding and practices that belong to superstitious, superstition and bid'ah is because this is still found in the life of society, especially in people who can be called as loyal heirs of the old community in Minangkabau.

\section{ACKNOWLEDGEMENT}

Alhamdulillah praise to Allah SWT, because the will and his Ridha authors can finish this article. The author realizes this article will not be completed without prayer, support and encouragement from various parties.

\section{REFERENCES}

A. B. Lapian. (2012). Indonesia dalam arus sejarah 5: Masa Pergerakan Kebangsaan. Ichtiar Baru van Hoeve. Alian. (2012). Metodologi Sejarah Dan Implementasi Dalam Penelitian. Criksetra, 2(2), 1-17.

Azra, A. (1989). Perspektif Islam di Asia Tenggara. Yayasan Obor Indonesia.

Djamal, M. (2014). The Origin of the Islamic Reform Movement in Minangkabau Life and Thought of Abdul Karim Amrullah. Studia Islamika, 5(3). https://doi.org/10.15408/sdi.v5i3.744

Edwar. (1981). Riwayat hidup dan perjuangan 20 ulama besar Sumatera Barat II. Islamic Centre Sumatera Barat.

Hamka. (1982). Ayahku: Riwayat Hidup Dr. H. Abdul Karim Amrullah dan Perjuangan Kaum Agama di Sumatera. Umminda.

Kamal, T. (2005). Purifikasi Ajaran Islam Pada Masyarakat Minangkabau. Angkasa Raya. 


\section{4 | IJECA (International Journal of Education and Curriculum Application)}

Vol. 1, No. 3, December 2018, pp. 5-14

Kayo, K. P. (2007). Muhammadiyah Dalam Pergaulan Tekstual. Hayfa Press.

Marjohan. (2010). Muhammadiyah Minangkabau. Surya Sarana Grafika.

Nain, S. A. (1988). Tuanku Imam Bonjol : Sejarah Intelektual Islam di Minangkabau. ESA.

Noer, D. (1982). Gerakan Moderen Islam di Indonesia 1900 - 1942. LP3ES.

Penghulu, I. H. D. R. (1978). Rangkaian mustika adat basandi syarak di Minangkabau. CV. Rosda Karya. 